\title{
'n Praktiese benadering tot die samestelling van 'n tweerigting- vakwoordeboek met Afrikaans en Italiaans as taalpaar
}

\author{
F. de Foglio (defoglio.hum@mail.uovs.ac.za) en H.J. Lubbe \\ (fgtlw.rd@mail.uovs.ac.za), Eenheid vir Taalfasilitering en -bemagtiging, \\ Universiteit van die Vrystaat, Bloemfontein, Republiek van Suid-Afrika
}

Opsomming: Deur die tempo van globalisering op handelsgebied ontstaan daar toenemend 'n behoefte aan tweerigtingvakwoordeboeke. Afrikaans is een van die hooftale in Suid-Afrika, en die landbousektor van die land is oorwegend Afrikaanssprekend. Aangesien een van die outeurs Italiaanssprekend is, by vertaling betrokke is en die leemte aan ' $n$ tweerigtingvakwoordeboek Afrikaans en Italiaans ervaar het, is kriteria bepaal vir die samestelling van so 'n vakwoordeboek op die gebied van die landbou-ekonomie tussen Afrikaans, 'n Germaanse taal, en Italiaans, 'n Romaanse taal. In agtereenvolgende afdelings word die algemene kriteria vir die samestelling van so ' $n$ woordeboek uiteengesit. Daarbenewens word voorafgaande werk wat verrig moet word, bespreek, asook die keuring van materiaal. Ten slotte word, aan die hand van gepaste voorbeelde, die leksikografiese beginsels toegepas. 'n Bylaag wat uit twintig lemmas bestaan, dien as voorbeeld van hoe so 'n vakwoordeboek daar behoort uit te sien.

Sleutelwoorde: AFRIKAANS, ITALIAANS, LEKSIKOGRAFIE, TERMINOGRAFIE, TERMINOLOGIE, TWEERIGTING, TWEETALIG, VAKLEKSIKOGRAFIE, VAKWOORDEBOEK, WOORDEBOEK.

\begin{abstract}
A Practical Approach to the Compilation of a Bi-directional Technical Dictionary with Afrikaans and Italian as Language Pair. Due to rapid globalisation in the commercial sphere, there is an ever-increasing need for the compilation of bilingual technical dictionaries. Afrikaans is one of the principal languages in South Africa, and the agricultural sector of the country is predominantly Afrikaans-speaking. Since one of the authors is Italianspeaking, is involved in translation, and has experienced the need for a bi-directional technical dictionary Afrikaans and Italian, criteria were determined for the compiling of such a technical dictionary in the field of agricultural economics between Afrikaans, a Germanic language, and Italian, a Romance language. In subsequent sections, the general criteria for compiling such a dictionary are outlined. In addition, the work that must precede this process is discussed, as is the selection of material. In conclusion, employing appropriate examples, the lexicographical principles are applied. An appendix comprising twenty entries serves as an example of what such a technical dictionary should look like.
\end{abstract}

Keywords: AFRIKAANS, BI-DIRECTIONAL, BILINGUAL, DICTIONARY, ITALIAN, LEXICOGRAPHY, LEXICOGRAPHY FOR SPECIAL PURPOSES, TECHNICAL DICTIONARY, 
TERMINOGRAPHY, TERMINOLOGY.

\section{Inleiding}

'n Oorheersende kenmerk van die huidige tydsgewrig is globalisering. Handelsgrense word toenemend opgehef, en in- en uitvoer neem toe. Dat Suid-Afrika nie hierdie tendens sal ontsnap nie, is vanselfsprekend. Na die opheffing van sanksies het Suid-Afrikaanse handel met die Europese Unie veelvuldig toegeneem. In hierdie proses speel doeltreffende kommunikasie uiteraard 'n belangrike rol. Dis ' $n$ feit dat die Europese Unie 'n meertalige taalbeleid het, en dat nie aangeneem moet word dat Engels outomaties die voorkeurhandelstaal is nie. Trouens, suksesvolle handel met oorsese lande vereis meer as die gewone kennis van Engels. Kennis van die teikengemeenskap se kultuur word vereis, en sy waardes, manier van onderhandel, behoeftes en begeertes moet ook in ag geneem word. Die Australiese ekonoom McCallum haal die Duitse Minister van Ekonomiese Sake aan: "If you wish to BUY from us, there is no need to speak German, but if you wish to SELL ..." (McCallum 1990: 54). Hy (McCallum 1990: 54) beweer dan ook: "Selling is facilitated by the use of the buyer's language."

Die doel van hierdie bydrae is om praktiese riglyne te verskaf vir die samestelling van 'n tweerigtingvakwoordeboek, spesifiek vir die taalpaar Afrikaans en Italiaans.

Hoewel Afrikaans as 'n relatief "klein" taal gekarakteriseer kan word, is dit een van die hooftale in Suid-Afrika wat deur 14,4\% van die bevolking gepraat word, teenoor 8,6\% Engels, 22,9\% Zulu en 17,9\% Xhosa (Statistics South Africa 1998). In teenstelling met die laasgenoemde twee tale beskik Afrikaans oor 'n uitgebreide vakwoordeskat.

Deur sy verbintenis met Nederlands, sowel diachronies as sinchronies, verleen Nederlands toegang, nie net tot één van die lande van die Europese Unie nie, maar tot al sestien (Lo Bianco 1996: 48):

The interesting consideration about the European Union is that to enter one economy, potentially and at least formally and legally, is to enter all 16 . They are interlinked. The same trade, tariff and packaging rules apply across the twelve - now sixteen - countries.

Lo Bianco (1996: 48) sê verder dat ander geleenthede vir Afrikaans wag in dele van Suid-Amerika (die Nederlandse Antille en Suriname), as gevolg van hierdie lande se koppeling met die groot Noord-Amerikaanse ekonomieë, en in Indonesië as poort tot die vinnig groeiende ekonomieë in Asië:

These links are not facilitated exclusively through foreign languages or English.

D.E. Barclay van die VSA, 'n gesaghebbende oor kwessies van globalisering, 
het tydens 'n besoek aan Suid-Afrika die rol van Afrikaans in die handelswêreld benadruk (Barclay 2000: 6-7):

Afrikaanssprekendes het 'n wanbegrip van die magte van globalisering enersyds en van die voortgaande en groeiende belangrikheid van "plaaslike" tale en kulture andersyds. Weens dít ken hulle gans te veel waarde toe aan die rol van Engels sowel in die globale ekonomie as in Suid-Afrika. [...] Die globale ekonomie staan in die teken van diversiteit, nie uniformiteit nie. 'n Groot deel van die bekoring van oorsee reis, bestaan in die ontmoeting met vreemde tale. Ek sou net sowel kon tuisbly as ek net Engels wou hoor en lees. Daarom vind ek dit vreemd, trouens dit is ' $n$ verleentheid om in Suid-Afrika te kom en net Engelse wynetikette te kry, of net Engelse toeristebrosjures aan die Kaapse Weskus.

In die lig van die feit dat die Suid-Afrikaanse landbousektor hoofsaaklik Afrikaanssprekend is (Statistics South Africa 1998), lê die voorbeelde wat vir die bespreking byeengebring is, op die gebied van die landbou-ekonomie. Afrikaanssprekende boere is oor die algemeen nie hoofsaaklik met bestaansboerdery gemoeid nie, maar bemark hulle produkte nasionaal en toenemend internasionaal.

As tweede lid van die taalpaar is Italiaans gekies omdat een van die outeurs 'n Italiaanse moedertaalspreker is, by vertaling betrokke is, en die leemte aan 'n tweerigtingvakwoordeboek Afrikaans en Italiaans ervaar het. Sover bekend, is daar geen leksikografiese studie van die verhouding tussen Afrikaans, 'n Germaanse taal, en Italiaans, 'n Romaanse taal nie. Slegs eentalige hulpmiddele bestaan wat dubbele vertaling (Afrikaans na Engels, en Engels na Italiaans) noodsaak. Tweetalige terminologiese databanke en vakwoordeboeke kan die vertaalproses geweldig versnel.

In die volgende afdelings word agtereenvolgens die algemene kriteria vir die samestelling van 'n tweerigtingvakwoordeboek bespreek, voorafgaande werk wat moet verrig word, die keuring van materiaal, en ten slotte word, aan die hand van voorbeelde, die leksikografiese beginsels toegepas. 'n Bylaag wat uit twintig lemmas bestaan, dien as voorbeeld van hoe so 'n vakwoordeboek daar behoort uit te sien.

\section{Algemene kriteria vir die samestelling}

Op ' $\mathrm{n}$ vraag aan die beeldhouer Rodin hoe om ' $\mathrm{n}$ beeld te maak, het hy geantwoord: "Neem 'n blok van steen en sny uit wat onnodig is" (Magay 1984: 221). 'n Gelyksoortige tegniek word deur die vakleksikograaf tydens die opstel van 'n vakwoordeboek gevolg. Taal vir Spesiale Doeleindes (TSD) is die soort taal wat in 'n vakwoordeboek opgeneem word, en die res, naamlik Taal vir Algemene Doeleindes (TAD) kan "uitgesny" word. Svensén (1993: 48) stel die TAD gelyk aan die taalgebruik van die gemiddelde moedertaalspreker. Dit gaan nie net oor woorde, uitdrukkings en sintaktiese patrone wat in die aktiewe gebruik van die meeste mense voorkom nie, maar ook oor wat in die passiewe kennis 
aanwesig is, m.a.w. die taal wat die meeste gebruikers herken en in bepaalde kommunikasietoestande gebruik. Die vaktaal (TSD), daarenteen, is volgens Alberts (1988: 3) die taal van bepaalde beroepsgroepe of vakdissiplines wat sekere kenmerke toon wat dit gedeeltelik van standaardtaal onderskei en daarvan vaktaal maak.

Vaktaal moet onder meer van twee aspekte rekenskap gee, naamlik 'n sosiolinguistiese aspek ("group language") en 'n ónderwerpverbonde aspek ("technical language") (Svensén 1993: 48). Vir Magay (1984: 221) is die samestelling van woordeboeke 'n eindelose reeks van besluite. Die eerste stap sou die beslissing omvat van wat ingesluit of uitgesluit behoort te word. In hierdie proses is drie faktore belangrik:

- die grootte van die woordeboek,

- die doel van die opstelling, en

- die bruikbaarheid daarvan.

Volgens Zgusta (1971: 218-219) behoort 'n omvattende generiese woordeboek van honderd duisend en meer tot ongeveer vier honderd duisend lemmas te bevat as daar ook gespesialiseerde terminologie ingesluit word. ' $n$ Middelslagwoordeboek sal tussen veertig duisend en sestig duisend lemmas bevat, terwyl 'n sakwoordeboek minder as twintig duisend lemmas bevat, en 'n klein woordeboek nie minder as tien duisend nie. Slegs gespesialiseerde woordeboeke (of vakwoordeboeke) kan kleiner as tien duisend terme wees en hulle sal dus gelyk wees aan woordelyste wat aan leksikografiese kriteria voldoen (Zgusta 1971: 220). Die bylae in De Foglio (2001) ressorteer ook hieronder.

Ongeag die grootte van die woordeboek, word die hele leksikon van 'n bepaalde taal benodig by die opstel daarvan. Hoe kleiner die woordeboek, hoe moeiliker is dit om lemmas te selekteer. Kritici en gebruikers (veral vertalers) koppel gehalte van die woordeboek aan dit wat daarin ontbreek (Magay 1984: 220). Dus behoort die gebruikersbehoeftes in ag geneem te word by die opstel van 'n woordeboek (vgl. hieroor Gove 1967: 5).

Oor die doel van die opstelling, m.a.w. die potensiële vaktaalgebruiker, moet vooraf helderheid verkry word. Cluver (1992: 40-42) onderskei drie belangrike groepe vaktaalgebruikers en dui aan watter soort definisies benodig word in vakwoordeboeke. Die drie groepe is studente, vakspesialiste en vertalers. Eersgenoemde groep moet verstaan dat begrippe in hiërargieë ingedeel kan word. Die student moet byvoorbeeld presies weet wat die verskil is tussen atmosfeer (bowegeskikte term), mesosfeer (ondergeskikte term: tussen die bowegeskikte en die newegeskikte term) en ionosfeer of eksosfeer (newegeskikte term, onderdele van die bowegeskikte term). Hiermee word bedoel dat die student meer ensiklopediese inligting nodig het. Die vakspesialis stel meer belang in die mees resente terme. Hy weet wat met 'n term bedoel word en soek in 'n vakwoordeboek eerder sinonieme en riglyne van die gebruik van die sinonieme as definisies. 'n Ander behoefte van die vakspesialis wat betref ' $n$ vakwoordeboek is verwysingsbronne. Dit gaan nie oor bronne met definisies/omskry- 
wings nie, maar eerder oor bronne wat die nuwe tendense in 'n bepaalde vakgebied aandui. Cluver (1992: 42) voeg dan by dat so 'n woordeboek wat die vereistes van die vakspesialis in ag neem, 'n kort lewe het.

Die laaste groep, die vertalers, hou hom besig met tweetalige vakwoordeboeke. Soos dit in die algemene leksikografie die geval is, is hierdie groep ook vir die vakleksikografie die veeleisendste gebruikersgroep. Vertalers benodig definisies, eksakte en erkende terminologie en voorbeelde wat die gebruik in verskillende registers aantoon. Volgens die behoeftes van die vertaler moet ' $n$ vakwoordeboek wat byvoorbeeld die geneeskunde behandel, terme soos abdomen, saam met sy verskillende sinonieme (buik, maag, pens) bevat, en naas hierdie inligting ook die gebruiksregister (Cluver 1992: 42). In die praktyk is die samesteller van 'n gespesialiseerde vakwoordeboek, soos in die geval van die bylae in De Foglio (2001), terselfdertyd die gebruiker. In so 'n geval is die opsteller op homself aangewese vir die identifisering van gebruikersbehoeftes. Aanvanklik moet so 'n woordeboek liefs nie in die kommersiële mark aangebied word nie, maar eerder eers aan die beperkte kring vertalers beskikbaar gestel word. Daar behoort ' $n$ wedersydse diensverhouding tussen die leksikografie en die vertaalwese te wees. Die vertaler behoort voortdurend terugvoer en riglyne aan die leksikograaf te verskaf om sodoende die leksikografiese werksaamhede en die gepaardgaande eindproduk so effektief moontlik te hou. Die leksikograaf sou veral aandag aan die vereistes van die vertaler kon gee en volkome afhanklik van hulle riglyne bly. Die vertaler is in der waarheid die grootste gebruiker van tweetalige woordeboeke en veral van vakwoordeboeke (vgl. Gouws 1991: 37 vir die moeilik oplosbare probleem van die bevrediging van die vertaler se behoeftes).

Die doel met die samestelling van 'n tweerigtingvakwoordeboek vir Afrikaans en Italiaans is spesifiek daarop gerig om vertalers behulpsaam te wees om die kommunikasieproses tussen die Suid-Afrikaanse en Italiaanse landbousektor te vergemaklik. As die gebruiker verdere inligting op die gebied van meer algemene lemmas of selfs grammatikale inligting benodig, sal hy dit moet gaan naslaan in 'n tweetalige generiese woordeboek.

Die bruikbaarheid van die vakwoordeboek, die derde faktor dus, is veral gerig op die aanwending deur die vertaler wat met die taalkombinasie Afrikaans-Italiaans werksaam is. Sodoende kan die probleem van dubbele vertaling tussen Afrikaans en Italiaans (van Afrikaans na Engels en van Engels na Italiaans, of 'n ander Romaanse taal en omgekeerd) oorkom word. Dit is noodsaaklik om in ag te neem dat die woordeboek in De Foglio (2001) slegs 'n vertaler of vakman kan dien wat beide tale, Afrikaans en Italiaans, magtig is. 'n Gewone gebruiker, die boer of die doeanebeampte wat geen kennis van een van die twee tale het nie, sal nie by die produk baat nie.

\section{Voorafgaande werk}

Voordat met die opstel van die vakwoordeboek begin word, moet volledige terminologielyste opgestel word, wat elektronies of in hardekopie geberg kan 
word. Die optekening van materiaal kan as verwysingsbron vir toekomstige vertaalopdragte dien, des te meer wanneer die vertaler weet dat daar geen leksikografiese hulpmiddele in dié taalkombinasie beskikbaar is nie. Lemmas en ekwivalente is in die volgende terminologielyste onder die afdeling landbou geklassifiseer en ingedeel:

- landbou-ekonomie,

- landboubemarking,

- landboukrediet,

- handelsterme, en

- landboubeleid.

Die bestaan van sulke selfopgestelde terminologiese versamelings moet tot ' $n$ beter verwerking volgens leksikografiese kriteria bydra. 'n Woordeboek is die vrug van die keuring van opgestelde terminologielyste en die bestaande literatuur soos vaktydskrifte in die betrokke twee tale. Die volgende tabel gee 'n uiteensetting van werk aan 'n vakwoordeboek.

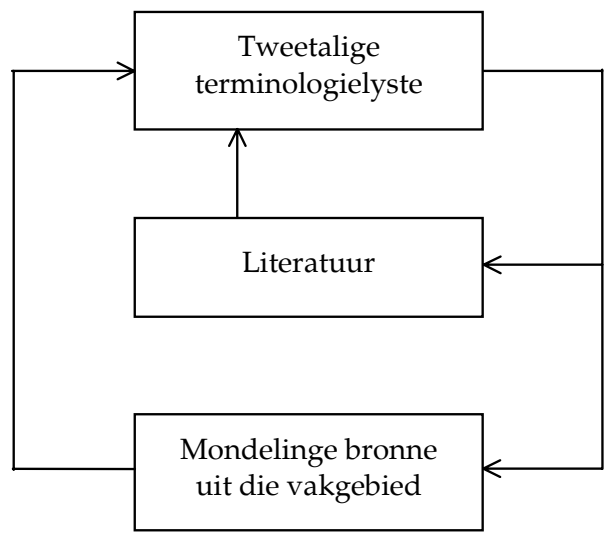

Die terminografiese werk aan 'n tweerigtingvakwoordeboek.

In die geval van die tweerigtingvakwoordeboek vir Afrikaans en Italiaans is terminologielyste uit vorige vertaalwerk en bestaande literatuur (soos aanbeveel deur Bergenholtz en Tarp 1995: 93) gebruik, asook Hartmann (1994: 291293) se "kontrastiewe tekstologie". Mondelinge terugvoer uit die vakgebied is verder bygevoeg. Hierdie maatreëls het tot die verryking van die korpus en die akkuraatheid van die tweetalige terminologielys bygedra.

Die beskikbare literatuur het hoofsaaklik bestaan uit tweetalige Afrikaanse en Engelse tydskrifte en eentalige Italiaanse tydskrifte oor landbou-ekonomie. Tweetalige ekonomie-vakwoordeboeke (Engels-Italiaans en Afrikaans-Engels) het ook bygedra tot semantiese inligting op die gebied van ekwivalente, tesame met die terugvoering van deskundiges op dié vakgebied (soos aanbeveel deur 
Bergenholtz en Tarp 1995: 92; Svensén 1993: 40).

\section{Keuring en bewerking van materiaal}

Vakwoordeboeke ondergaan 'n strenger keuring van materiaal as meer omvattende algemene tweetalige woordeboeke. Volgens Svensén (1993: 40) is "betroubaarheid" die faktor wat elke leksikograaf in die keuringsproses behoort na te streef. Dit is nie genoeg dat die leksikograaf slegs op sy linguistiese vermoë staatmaak vir die keuring van materiaal wat in 'n woordeboek opgeneem word nie, maar hy moet ook die betroubaarheid van die terme wat in die praktyk gebruik word, in ag neem. In dié verband beweer Svensén (1993: 40):

The selection for a dictionary must be authentic, that is to say it must include only such linguistic occurrences as actually exist. In order to be sure that a certain linguistic occurrence really is authentic, the lexicographer must find evidence for it in independent sources.

Met onafhanklike bronne word hoofsaaklik bedoel dat mondelinge bronne ook geraadpleeg moet word om 'n bepaalde ekwivalent vas te stel.

Volgens Cluver (1992: 35) is die begrippe agter die vaklemmas meer eksplisiet ingeperk as dié van die lemmas van die algemene taal. Een voordeel van die vakleksikograaf, in vergelyking met die algemene leksikograaf, is dat sy definisies meer eksak en dus kontroleerbaar is. Hierdie faktor versnel ook die keuringsproses van die vakleksikograaf op ' $n$ bepaalde vakgebied.

In die geval van die tweerigtingvakwoordeboek is tekste uit landbou-ekonomiese tydskrifte sorgvuldig "geskandeer" om te bepaal watter terme spesifiek in die taal van die landbou-ekonomie voorkom. Hoewel algemene lemmas soos bees of vrug wel taamlik algemeen in die landbou-ekonomie voorkom, is hulle nie opgeneem nie omdat veronderstel is dat hulle reeds in algemene tweetalige woordeboeke voorkom.

Woordelyste en woordeboeke oor algemene landbou is geïdentifiseer en die keuring in die afgebakende veld, landbou-ekonomie, is gedoen. Die Italiaans-Engelse ekonomiese woordeboeke was nuttiger as die Afrikaans-Engelse verwante woordeboeke in terme van die reikwydte van ekwivalente. Nietemin was laasgenoemdes onmisbare verwysingsbronne.

In die opstelling van sowel ' $n$ vakwoordeboek as ' $n$ algemene tweetalige woordeboek word primêre én sekondêre bronne gebruik (Svensén 1983: 53-54). Primêre bronne bestaan hoofsaaklik uit mondelinge en geskrewe bronne, terwyl sekondêre bronne woordeboeke insluit. In die leksikografiese werk is van verskillende primêre bronne (tydskrifte, werklike taal van die spesifieke vakgebied en mondelinge gesprekke) en sekondêre bronne (verskillende tweetalige en eentalige woordelyste) gebruik gemaak. Hartmann (1994: 291-293) se tegniek van parallelle tekste is uitvoerig vir die keuring en vasstelling van ekwivalente gebruik.

Tekste verkry uit primêre tweetalige bronne, is met persone, aktief in die 
vaktaal, gekontroleer. Uit tweetalige Engelse en Afrikaanse tydskrifte is eerstens Afrikaanse en Engelse ekwivalente verkry. Hulle is as basis gebruik om Italiaanse ekwivalente na te slaan en, indien nodig, ook te vertaal. Die Italiaanse ekwivalente is sorgvuldig met persone wat in die vakgebied werksaam is, gekontroleer. 'n Ekonomiese woordelys van agt honderd lemmas betreffende landbou, handel en die bemarking van landbouprodukte, wat tydens die vertaalpraktyk saamgestel is, is in die woordeboek opgeneem.

Volgens Svensén (1983: 50) bestaan vaktaal nie net uit woorde nie. Verbindings, kollokasies en uitdrukkings behoort ook in 'n vakwoordeboek opgeneem te word. Hy wys daarop dat hierdie aspek nie noodwendig altyd in vakwoordeboeke in ag geneem word nie, omdat hulle gewoonlik slegs as bronne gebruik word om ekwivalente vinnig te bekom. Daar bestaan eintlik geen rede vir die verskillende hantering van tegniese en algemene taal nie.

Vir die keuringswerk is dit veiliger om 'n reeds bestaande, alfabetiese korpus lemmas van 'n bepaalde vakgebied aan te wend. So 'n indeks sou die werk van die leksikograaf aansienlik vergemaklik (Bergenholtz en Tarp 1995: 101). Dikwels is daar geen bestaande lys van die behandelde vakgebied nie en, soos in die geval van hierdie studie, is die leksikograaf op homself aangewese om die keuring te doen uit bepaalde vaktydskrifte, wat per slot van rekening die beste bron van dié gebied se taal behoort te wees.

Omdat geskikte elektroniese infrastrukture ontbreek het tydens die terminografiese werk, is die algehele verwerking hoofsaaklik met behulp van elektroniese ontledingstate uitgevoer, wat onder meer tot die elektroniese alfabetisering van die finale woordelys bygedra het. Bergenholtz en Kaufmann (1997: 107 e.v.) bespreek die rol van rekenaartegnologie by terminografiese werk. 'n Tydelike drietalige woordelys (Afrikaans-Italiaans-Engels) het ontstaan ná akkurate keuring uit literatuur, tydskrifte van landbou en landbou-ekonomie, saam met mondelinge gebruik. Die ontledingstaat het rekenaarmatig gehelp om Afrikaanse en Italiaanse lemmas van die Engelse lemmas af te sonder. Hierdie lemmas is omgekeer volgens die behoeftes van die rigting waarin gewerk is. Grammatikale inligting is nie bygevoeg tydens die terminografiese werk nie en dit het eers in 'n later stadium (dus tydens die leksikografiese verwerking) plaasgevind.

\section{Toepassing van leksikografiese beginsels}

Uit die terminografiese werksaamhede het 'n terminologie van landbou-ekonomie tussen Afrikaans en Italiaans ontstaan. Die vereiste was om 'n leksikografiese werk ('n woordeboek) tot stand te bring en leksikografiese beginsels is dus toegepas.

\subsection{Woordeboekstruktuur}

Om 'n oorsigtelike struktuur te verseker, is die volgende kriteria in berekening 
gebring:

(a) Makrostruktuur As makrostrukturele element verskaf die lemma inligting oor die klem in die vorm van 'n klemteken (belas'ting) in die rigting Afrikaans-Italiaans, of in die vorm van 'n onderstreepte klinker (vendere) in die rigting Italiaans-Afrikaans.

Op makrostrukturele vlak kan die lemma in toepaslike gevalle 'n simbool (|) bevat wat lettergreepskeiding aandui. Hierdie simbool is belangrik vir die verskaffing van inligting oor die verskillende vorme van die woord. Die morfologie word in die mikrostruktuur aangedui.

In die rigting Afrikaans-Italiaans kan byvoorbeeld die volgende aangetref word:

$$
\begin{aligned}
& \text { be } \mid \text { drag', }^{, ~ s} \text { (-drae) }, \ldots \\
& \text { addision } \mid \text { eel }^{b} \text { (-ele), ... }
\end{aligned}
$$

In die rigting Italiaans-Afrikaans is die grammatikale en morfologiese inligting van die lemma deel van die mikrostruktuur:

$$
\begin{aligned}
& \text { acces } \mid \text { so, s.m., (-si), ... } \\
& \text { accaparr } \mid \underline{\text { are }, ~} w .,(-\mathbf{a t o}), \ldots \\
& \text { agrari } \mid \mathbf{o}(-\mathbf{a}), b .,(-\sim /-\mathbf{e}), \ldots \\
& \text { acquiren } \mid \text { te, }, \text { s.m/v., (-ti), ... }
\end{aligned}
$$

(b) Mikrostruktuur In die rigting Afrikaans-Italiaans word vertaalekwivalente met grammatikale inligting van Italiaans voorsien:

in'vorder, $w$ (-ge-), riscuotere (tasse); aar, $s(-\mathbf{s})$, esattore $m ; \sim$ baar, $b$ (-bare), tassabile, imponibile; $\sim$ ing, ${ }^{s}$ riscossione $v$; ing op lening, rimborso $m$ del credito; ingskoste, costo $m$ di riscossione.

In die meeste vakwoordeboeke in die Germaanse tale is daar min of geen grammatikale inligting ingesluit nie, maar vir sowel Germaanse as Romaanse behoeftes is dit noodsaaklik om grammatikale inligting te verskaf. Grammatikale inligting is soos volg bepaal: in die rigting Afrikaans-Italiaans is die woordsoortlikheid telkens ná die lemma aangedui $(w=$ werkwoord; $s=$ selfstandige naamwoord; ${ }^{b}=$ byvoeglike naamwoord; $b w=$ bywoord). Hierdie inligting word verskaf om vir die behoeftes van die Italiaanssprekende gebruiker wat onderskeidingsinligting omtrent woordsoortlikheid in Afrikaans sal benodig, voorsiening te maak. Genoemde onderskeiding sal oorbodig wees vir die Afrikaanssprekende gebruiker, en dus is die inligting met verkleinde boskrifletters aangetoon. Hierdie werkwyse behoort ook die toegangstruktuur te verbeter. 
Ná die lemma word die grammatikale inligting soos volg hanteer: woordsoortlikheid en/ of genus, meervoud, verlede tyd, vertaalekwivalente, kollokasies en voorbeeldsinne.

In die rigting Italiaans-Afrikaans word die woordsoortlikheid met 'n ander lettertipe aangetoon (bv. acquisto, s.m., aankoop), waar woordsoortlikheid (s.m.) en genus (s. $\underline{m}$.) 'n belangrike faktor vir die Afrikaanssprekende gebruiker word. ${ }^{1}$ Laasgenoemde strategie is eerder gebruik om inligting oor die genus, wat tipies van die Romaanse tale is, aan te dui. In die rigting Italiaans-Afrikaans word daar meer aandag gegee aan die Afrikaanssprekende gebruiker wat meer inligting oor die genus van Italiaans benodig.

Indien nodig is meerfunksionaliteit aangedui. Die verskillende woordsoortlike funksies van 'n lemma met dieselfde vorm (soos besit) word met nommers aangedui:

besit', $\mathbf{1}^{\mathrm{s}}$, possesso $m$, proprietà $v$, bene $m$, demanio $m$; nemer, occupante $m$; titolare $m$; neming, occupazione $v$; prendita $v$ di possesso; $\sim$ reg, diritto $m$ di proprietà, dominion $m .2^{w}(\sim)$, possedere; occupare ...

(c) Toegangstruktuur 'n Effektiewe toegangstruktuur is noodsaaklik vir die gebruik van 'n woordeboek. Dit dien as "soekpad" (Gouws 1996: 19) vir die gebruiker om die benodigde inligting te bekom. In hierdie werk word die inligting op so 'n toeganklike wyse moontlik aangebied. As die gebruiker kollokasies of voorbeeldsinne benodig, sal hy dit in kursief gedruk vind, terwyl samestellings met die lemma in vet gedruk is:

wins, ${ }^{s}$ (-te), utile $m$; profitto $m$; reddito $m$; tornaconto $m$; frutto $m$; $\sim$ delende obligasie, obbligazione $v$ con partecipazione; $\sim$ deling, partecipazione $v$ agli utili, compartecipazione $v$ agli utili; $\sim$ delingsertifikaat, certificato $m$ di partecipazione agli utili; gewende belegging, investimento $m$ remunerativo; gewendheid, s redditività $v$; grens, margine $m$ di guadagno; $\sim$ marge, margine di utile, margine di profitto; s saldo, (ONVERDEELDE WINS), profitti $m$ indivisi; deelgeregtigheid in die $\sim, \Rightarrow$ WINSDELING; herbelegde $\sim$; herinvesteerde , reinvestimento $m$ degli utili; ingehoue te; teruggehoue , profitti non distributiti, utili trattenuti; meevaller , utili $m$ straordianari; onuitgekeerde (onverdeelde) , profitti non distribuiti; papier , utile sulla carta; skoon maak, chiarificare; guadagnare al netto; suiwer , profitto netto.

'n Voorbeeld uit die Italiaans-Afrikaanse rigting sien soos volg daaruit:

accredito, s.m., (CREDITO), krediet; kreditering; bancario, bankkrediet; nota di $\sim$, kredietnota; somma in , kredietbedrag.

Daar word sover moontlik probeer om die inligting wat in vet gedruk is voor die inligting wat in kursief gedruk is te laat verskyn. Die lemma word in die 
mikrostrukturele veld herhaal in die vorm van 'n tilde ( ). Hierdie strategie behoort die woordeboek se leesbaarheid te verhoog en die gebruiker in staat te stel om woorde rondom die lemma binne die woordeboekartikel te vind. ' $n$ Interne toegangstruktuur ("inner access structure", vgl. Gouws 1996: 19-20) word ook voorsien in die vorm van die alfabetisering van inligting, in kursief of in vet gedruk.

(d) Mediostruktuur Twee tipes verwysingsadresse ("reference addresses", vgl. Gouws en Prinsloo 1998: 20-21) word in die woordeboek gebruik. Albei is eksterne verwysingsadresse ("external reference addresses", vgl. Gouws en Prinsloo 1998: 20). Die funksionaliteit van die woordeboek word hiermee verhoog (Gouws en Prinsloo 1998: 21), en die leesbaarheid daarvan verbeter.

Die eerste tipe verwysingsadres is 'n stelsel van kruisverwysings in klein hoofletters. Hulle word deur 'n verwysingsaanwyser $(\Rightarrow)$ voorafgegaan om die inligting wat in die lemma te vinde is, aan te toon (vgl. Gouws en Prinsloo 1998: 19). Voorbeelde hiervan is die volgende:

importeer', ${ }^{w}$ (geïm-) $\Rightarrow$ INVOER ${ }^{w}$.

uit'gifte, ${ }^{s}(-\mathbf{s}) \Rightarrow$ EMISSIE.

'n Tweede tipe verwysingsadres dien om sinonieme van die lemma aan te dui wat in ander dele van die woordeboek voorkom. Hierdie metode stel die gebruiker in staat om hierdie sinonieme na te slaan.

obliga'sie, ${ }^{s}$ (-s), obbligazione $v$; houer, (SKULDBRIEFHOUER; VERBANDHOUER), obbligazionista $m$.

skuld, ${ }^{s}$ (-e), debito $m$; akte, titolo di debito; brief, certificato obbligazionario; obbligazione; $\sim$ briefhouer $\Rightarrow$ OBLIGASIEHOUER.

verband', ${ }^{s}(-\mathbf{e})$, ipoteca $v$, contratto $m$ ipotecario; akte, obbligazione $v$ ipoteca; finansiering, finanziamento $m$ ipotecario; $\sim$ houer $\Rightarrow$ OBLIGASIEHOUER; krediet, credito $m$ ipotecario; lening, mutuo $m$ ipotecario, prestito ipotecario; obligasie $\Rightarrow$ VERBANDAKTE; rente, interesse $m$ ipotecario; sekuriteit, garanzia $v$ ipotecaria; $\sim$ skuld, debito $m$ ipotecario; vruggebruikers , ipoteca usufruttuaria.

'n Sirkelstruktuur ("circular structure", vgl. Gouws en Prinsloo 1998: 19) word ook aangewend, hoewel dit aanleiding kan gee tot onvergenoegdheid by sekere "ongeduldige" woordeboekgebruikers:

concedente, s.m. $\Rightarrow$ CONCESSORE.

concessore, s.m., (CONCEDENTE), begiftiger; gewer; skenker. 


\subsection{Hantering van vertaalekwivalente en sinonieme}

Die verskillende betekenisse van die vertaalekwivalente word met ' $n$ kommapunt (;) geskei en die sinonieme met ' $n$ komma (,) o.a. soos in die Groot Woordeboek/Major Dictionary van Eksteen (199714). In ander woordeboeke word vertaalekwivalente wat in betekenis verskil soms met nommers aangetoon. Vir die doeleindes van hierdie werk, en ook as gevolg van die gespesialiseerde aard daarvan, is besluit om eerder leestekens te benut aangesien nommers reeds gebruik is om woordsoortlikheid aan te dui. Hierdie strategie behoort weereens die leesbaarheid van die woordeboek te verbeter (d.w.s. 'n beter toegangstruktuur te verskaf).

Sinonieme word sorgvuldig binne die mediostrukturele vlak met kruisverwysings, verwysingadresse en sirkelstrukture aangedui. Dit handel hoofsaaklik oor sinonieme wat, naas lemmas, die vertaalekwivalente verskaf. Volgens die besluit van die opsteller word dit op mediostrukturele vlak hanteer.

\subsection{Grammatikale inligting in vakwoordeboeke}

Soos ten opsigte van die taalpaar Engels-Italiaans in die geval van Favati (1990), is ook ten opsigte van die taalpaar Afrikaans-Italiaans grammatikale inligting oor Italiaans noodsaaklik vir die Afrikaanssprekendes, en omgekeerd het die Italiaanssprekendes naas die vertaalekwivalent ook semantiese en grammatikale inligting oor Afrikaans nodig.

Uit die vertaalpraktyk is dit duidelik dat blote vertaalekwivalente ontoereikend is weens die onbekendheid van die twee tale onderling. Die probleem word soos volg benader: Waar Italiaans die doeltaal is, word die lemmabewerking naas die vertaalekwivalent ook voorsien van grammatikale inligting, woordsoortlikheid en genus, iets wat Afrikaans, en ook Engels, glad nie het nie. Daarbenewens is die vervoeging van die werkwoordstelsel in Italiaans baie meer flekterend as in Afrikaans ten opsigte van tempus, persoon, getal en kongruensie. Ook vir 'n tweetalige Afrikaans-Italiaanse vertaler of vakman is grammatikale inligting oor die onderskeie tale op die gebied van toegangstruktuur belangrik, want grammatikale inligting speel beslis 'n rol om die vinnige raadpleging van die lemma te bewerkstellig.

Grammatikale inligting kan die vakman meer help as die vertaler wat beide tale en grammatikas beheers. Die inligting sal ook die vertaler in staat stel om vinnig te onderskei tussen die woordsoortlikheid. 'n Voorbeeld hiervan is:

Administrasie, Amministrazione n.v.

Genusaanduiding in Italiaans is noodsaaklik vir die Afrikaanssprekende gebruiker wat min kennis van Italiaanse genusverskille het. Die woord Amministrazione met 'n n.v. (d.w.s. naamwoord/vroulik) wys dadelik aan die gebruiker dat dit 'n vroulike naamwoord is en dat die lidwoord la is en nie il nie, 
m.a.w. skrapping van die klinker a (l'amministrazione uit la amministrazione) het plaasgevind. Vir 'n ervare vertaler, spesifiek vir die Afrikaanssprekende vertaler, kan hierdie grammatikale inligting ook baie nuttig wees al weet hy dat die genus van Italiaans afgelei kan word van die uitsonderlike klinker $e$ aan die einde van die woord amministrazione, wat nie noodwendig vroulik of manlik is nie. ${ }^{2}$ In teenstelling met Italiaans ken Afrikaans geen genus of vervoeging nie, en dus hoef hierdie inligting nie verstrek te word nie. Daar word natuurlik aangeneem dat die Italiaanssprekende gebruiker van so 'n vakwoordeboek (vertaler of tweetalige vakman) reeds weet dat Afrikaans nie sulke grammatikale inligting bevat nie.

\section{Slot en aanbevelings}

Vir die opstel van 'n tweerigtingvakwoordeboek met Afrikaans en Italiaans as behandelde taalpaar, moet vooraf empiriese navorsing gedoen word om die behoeftes en leemtes van die gebruiker van die betrokke tale te bepaal. Indien die gebruiker hoofsaaklik 'n vertaler of tweetalige vakman is, kan 'n meer gevorderde kennisagtergrond aanvaar word.

Hoewel so 'n vakwoordeboek nie geskik is vir 'n groot publiek of mark nie, kan leksikografiese navorsing wél aangemoedig word tussen Afrikaans en Italiaans, en wel in terme van 'n tweetalige tweerigtingaanleerderwoordeboek wat die behoeftes van die Afrikaanse gebruiker ten opsigte van Italiaans sal dien.

Standaardkriteria van die moderne vertalende leksikografie sal aangepas moet word. 'n Onderliggende databasis in Afrikaans sal saamgestel moet word vir ' $n$ moontlike tweetalige leksikografiese werk met Afrikaans en Italiaans as behandelde taalpaar. Vermoedelik sal die mark en die belangstelling in so ' $n$ woordeboek groter in Suid-Afrika as in Italië wees. Suid-Afrika regverdig die projek aangesien Italiaans as 'n belangrike wêreldtaal beskou word, maar dieselfde kan nie in Italië verwag word nie, aangesien die belangstelling vir Afrikaans nog nie so ontwikkel is nie.

Indien later ook in Italië 'n groter behoefte sal ontstaan, kan dieselfde databasis dien om 'n tweetalige woordeboek saam te stel wat die Italiaanse gebruiker in ag neem.

As voorbeeld hoe so 'n vakwoordeboek daar behoort uit te sien, word twintig lemmas in ' $n$ bylaag aangegee.

\section{Aantekeninge}

1. Uit 'n ondersoek na die gebruikersaspek kan daar afgelei word dat die potensiële tweetalige gebruiker eerder Afrikaanssprekend as Italiaanssprekend is. Die mark is potensieel doeltreffender in Suid-Afrika as in Italië, en dus word meer op die Suid-Afrikaanse gebruiker gefokus.

2. Naamwoorde en byvoeglike naamwoorde in Italiaans dra genus-inligting. As naamwoorde 
met ' $n o$ eindig, gaan dit oor manlike naamwoorde, as hulle met ' $n a$ eindig, is hulle vroulike naamwoorde. Sommige Italiaanse woorde eindig op $e$ en dit kan óf na manlike óf na vroulike naamwoorde verwys. In hierdie geval kan slegs woordeboeke die regte inligting oor genus, soos in amministrazione (v) en agente (m), aan 'n anderstalige persoon gee.

\section{Bibliografie}

Alberts, M. 1988. Die rekenarisering van vakleksikografie. Suid-Afrikaanse Tydskrif vir Taalkunde 6 (1): $1-19$

Barclay, D.E. 2000. Engels: Te veel klem. Afrikaans Vandag 7(3): 6-7.

Bergenholtz, H. en U. Kaufmann. 1997. Terminography and Lexicography. A Critical Survey of Dictionaries from a Single Specialised Field. Journal of Linguistics 18: 91-125.

Bergenholtz, H. en S. Tarp. 1995. Manual of Specialised Lexicography. Amsterdam: Benjamins.

Cluver, A.D. de V. 1992. Die verskille en ooreenkomste tussen algemene en vakleksikografie. National Terminology Services 1992: 32-48.

De Foglio, F. 2001. Leksikografiese kriteria vir 'n tweerigtingvakwoordeboek: Afrikaans-Italiaans en Italiaans-Afrikaans. Ongepubliseerde M.A.-skripsie. Bloemfontein: Universiteit van die Vrystaat.

Eksteen, L.C. (Red.). 199714. Groot Woordeboek / Major Dictionary. Kaapstad: Pharos.

Favati, F. 19902. Dizionario di agricoltura. English-Italian, Italiano-Inglese. Bologna: Edizioni Agricole.

Gouws, R.H. 1991. Kommunikatiewe ekwivalensie in vertalende woordeboeke - 'n probleem vir die vertaler. Suid-Afrikaanse Tydskrif vir Taalkunde 10(1): 37-42.

Gouws, R.H. 1996. Bilingual Dictionaries and Communicative Equivalence for a Multilingual Society. Lexikos 6: 14-31.

Gouws, R.H. en D.J. Prinsloo. 1998. Cross-referencing as a Lexicographical Device. Lexikos 8: 17-36.

Gove, P.B. 1967. The Dictionary's Function. Gove, P.B. (Red.). 1967. The Role of the Dictionary: 5-8. Indianapolis: The Bobbs-Merrill Co.

Hartmann, R.R.K. 1994. The Use of Parallel Text Corpora in the Generation of Translation Equivalents for Bilingual Lexicography. Martin, W. et al. 1994: 291-297.

Hartmann, R.R.K. 1984 (Red.). LEXeter '83 Proceedings. Papers from the International Conference on Lexicography at Exeter, 9-12 September 1983. Tübingen: Max Niemeyer.

Lo Bianco, J. 1996. Language as an Economic Resource. Language Planning Report 5 (1). Pretoria: DACST.

Magay, T. 1984. Technical or General: Problems of Vocabulary Selection in a Medium-size Bilingual Dictionary. Hartmann, R.R.K. (Red.). 1984: 221-225.

Martin, W. et al. (Reds.). 1994. Euralex '94 Proceedings. Papers Submitted to the 6th EURALEX International Congress on Lexicography in Amsterdam, The Netherlands. Amsterdam: Free University Press.

McCallum, A. 1990. Internationalising the Operations of Australian Business with Particular Reference to the Role of Language. Language is Good Business, Conference Proceedings. Melbourne: NLLI.

Statistics South Africa. 1998. The People of South African Population Census 1996: Census in Brief. Report No. 03-01-11 (1996). Pretoria: Statistics South Africa.

Svensén, B. 1993. Practical Lexicography — Principles and Methods of Dictionary Making. Oxford: Oxford University Press.

Zgusta, L. 1971. Manual of Lexicography. Den Haag: Mouton. 
Bylaag

\section{Afrikaans - Italiaans}

klant, ${ }^{s}$ (-e), cliente $m$, compratore $m$; acquirente $m$; $\sim \mathbf{e}$, clientela $v$; esteun, supporto $m$ alla clientela.

kla'ring, $s$ compensazione $v$, chiarificazione $v$; pratica $v$ di sdoganamento (dogana); sooreenkoms, accordo $m$ di compensazione.

klein'handel, ${ }^{s}$ commercio $m$ al minuto; $\sim$ aar, $s$ (-s/-are), trafficante $m$, rivenditore $m$, commerciante $m$ al minuto; (s)ketting, catena $v$ al dettaglio; $\sim(\mathbf{s})$ mark, mercato $m$ al dettaglio; $\sim(s)$ prys, prezzo $m$ al minuto, prezzo al dettaglio; $\sim($ s)prysindeks, indicizzazione $v$ del prezzo al minuto; $\sim(\mathbf{s})$ verkope, vendite $v$ al dettaglio.

klein'kas, ${ }^{s}$ piccola cassa, fondo $m$ per le piccole spese; uitgawes, spese $v$ minute.

kleur, $s$ (-e), colore $m$, tintura $v$ (delle pelli).

kliënt', s (-e), cliente $m$; ediens, servizio $m$ clienti; eel', clientela $v$.

klousu'le, s (-s), clausola $v$; articolo $m$; paragrafo $m$; beskermings , clausola di salvaguardia \{C.E.E.\}; bygevoegde $\sim$ AANHANGSEL; kontrak , clausola di (del) contratto; meesbegunstigings , clausola della nazione più favorita; omvattende $\sim$, clausola generale; straf $\sim$, (STRAFBEPALING), clausola penale.

knel'punt, s strozzatura $v$.

koëffisiënt', s (-e), (VERHOUDING), rapporto $m$; proporzione $v$.

koel'kamer, $s(-s)$, camera $v$ frigorifero.

\section{Italiaans - Afrikaans}

condutt $\mid$ ore, s.m., (-ori), (CONDUTTORE DI AZIENDA), plaasbestuurder; boer.

conduzione, s.v., (AMMINISTRAZIONE; DIREZIONE; GESTIONE), bestuur; di un fondo, landgoedbestuur; agricola in affitto, gehuurde boerdery; diretta, direkte bestuur.

confezioname $\mid$ nto, s.m., (IMBALLAGGIO), verpakking; della frutta, vrugteverpakking.

consegnare, $w .,($-ato), lewer; verskaf; voorsien.

consi | glio, s.m., (-gli), raad; sulla ricerca agraria, landbounavorsingsraad. 
consor $\mid$ zio, s.m., (-zi), konsortium; unie; trust; agrario, landbou-unie; bancario, sindikaat; finanziario, (CONSORZIO DI EMISSIONE), onderskrywingsindikaat; per investimenti, effektebelegging; effektetrust.

consule $\mid$ nte, s.m/v, (-nti), konsultant, raadgewer; agrario, landboukonsultant, landboukundige raadgewer; $~$ di marketing, (CONSULENTE ADDETTO ALLA COMMERCIALIZZAZIONE), bemarkingsadviseur.

consumato $\mid$ re, s.m., (-ri), s.v., (UTENTE), verbruiker; finale, uiteindelike verbruiker.

consumatri $\mid$ ce, s.v., (-ci) $\Rightarrow$ CONSUMATORE.

consum $\mid$ o, s.m., (-i), verbruik; alimentare, voedselverbruik; annuo, jaarverbruik, jaarlikse verbruik; $\sim$ di capitale, kapitaalvertering; $\sim$ di derrate, verbruik van voedingstowwe; $\sim$ di prodotti agricoli, verbruik van landbouprodukte; $\sim$ individuale $\Rightarrow$ CONSUMO PRO CAPITE; $\sim$ interno, binnelandse verbruik; pro capite, verbruik per capita, verbruik per hoof, per capita-verbruik; crisi di , verbruikskrisis; principali generi di , stapelartikels; stapelgoedere, stapelprodukte. 